\title{
VALENTĪNES LASMANES GADSIMTA STĀSTS
}

\author{
Māra Zirnīte, $M g$. philol., Latvijas Mutvārdu vēstures pētnieku asociācijas
}

Dzīvesstāsts valdes priekšsēdētāja

"Nacionālās pretošanās kustības dalībnieces Valentīnes Lasmanes dzīvesstāsts, no vienas puses, ir leǵendāra cilvēka memuāri, kas vieš lielāku skaidrību par Latvijas nacionālo pretestību Otrajā pasaules karā, par sabiedrības noskaņojumu, studentu dz̄ivi Rīgā pagājušā gadsimta trīsdesmitajos un arī par citiem pārdomu un zinātniskas izpētes vērtiem tematiem. No otras puses, vinas rakstītais škiet kā vecvecmāmiņas vēstījums jaunajai paaudzei," motivāciju atminu pārtapšanai grāmatā (2020) paskaidro tās iniciators un literārais sakārtotājs Gaitis Grūtups (Nakts nav tikai gulēšanai: Valentīnes Lasmanes dzīvesstāsts. Sak. G. Grūtups. Rīga: Mansards, 2020).

Dzīvesstāsta jēdziens mutvārdu vēstures pētījumos un publikācijās nozīmē cilvēka paša veidotu vairāk vai mazāk izsmeḷošu stāstu par savu dzīves gājumu. Tas var būt gan autora uzrakstīts vai dzīvesstāstu intervijās radīts, gan, kā šajā gadījumā - stāstīto un rakstīto atmiṇu apvienojums, kur kompozīciju sakārto pieredzējis literāts.

Nodrošināts ar zinātniskiem komentāriem (Dr. phil. Aija Priedīte, Dr. hist. Kaspars Zellis), dzīvesstāsts iegūst dokumentāras liecības nozìmi. V. Lasmanes stāstam tas ir sevišķi svarīgi, jo viṇa bija klāt, piedalījās un redzēja vēstures notikumus, pār kuriem joprojām klājas liela neskaidrības migla. Kopš savas piedzimšanas (1916) viņa ar gaišu prātu pasaulē nodzīvoja 102 gadus.

Atminu stāsts ir starpnieks starp to, kas realitātē noticis, un to, kā notikušo pārdzīvojis, sapratis un pēc garāka vai īsāka laika attēlo stāstītājs. Dzīves īstenību no stāsta palīdz izlobīt konteksts - atcerēšanās apstākḷi, vieta un laiks, iesaistītās personas. Viss minētais iespaido gan stāsta saturu, stāstītāja jeb autora attieksmi, gan izteiksmes veidu un radošo izpausmi atminu tēlojumā. Stāstīto atmiņu tapšanas apstākḷu izvērtējumam ir tikpat liela nozīme kā jebkura dokumentāra avota ticamības pamatojumam. Tāpat jāsaprot, kādas pārvērtības piedzīvo intervijas teksts, kas radies visai intīmi, tikai dažu cilvēku starpā, kad to gatavo publiskam sniegumam.

Nav jau tā, ka par V. Lasmani iepriekš neviens nebūtu neko dzirdējis. Draugu viñai ir daudz arī Latvijā, tomēr jaunatnes vidū V. Lasmanes vārds nav pazīstams. Vecākā paaudze vēl atceras, kā viņas prototips izmantots Arvīda Griguḷa romānā Kad lietus un vēji sitas $\log \bar{a}^{1}$, ko Aloizs Brenčs apspēlējis tā paša nosaukuma padomju detektīvfilmā par nacionāli jūtīgo tēmu. Kā vienā, tā otrā dominē ideologiskā tendence, tomēr laikabiedri caur propagandu uztvēra konkrētus notikumus, par ko tolaik vēsture klusēja. Interesanti, ka kino režisors Pēteris Krilovs, savas filmas Uz spēles Latvija (2014) izpētes gaitā atklājis, ka rakstnieks romānu būvējis no iesaistìta cilvēka atmināām, par kurām samaksājis krietnu summu².

Reālo Valentīni sastopam gan vēsturiski dokumentārajā režisora P. Krilova kinofilmā Uz spēles Latvija, ko redzējuši skatītāji Latvijā, gan arī zviedru režisora Ulles Hēgera (Olle Häger) filmā Pēdējā laiva uz Jūrkalni, kas tapa 2001. gadā, bet Latvijā uz ekrāniem nav parādīta.

Jaunākos laikos vinas viedokli un notikumu liecības uzklausījuši vēstures pētnieki. Tās iekḷautas Dzintara Ërgḷa ${ }^{3}$, Ulda Neiburga ${ }^{4}$

1 Grigulis, A. (1965) Kad lietus un vēji sitas logāa. Rīga : Latvijas Valsts izdevniecība.

2 Kvīts par darījumu ar Rihardu Zandi glabājas Rakstniecības un mūzikas muzeja arhīvā A. Griguḷa fondā.

3 Ērglis, Dz. (2010) Latvijas Centrālās padomes aktivitātes (1943-1945): Laivu akcijas. Latvijas valstiskumam 90. Rīga : Latvijas vēstures institūta apgāds, 280-291; (2003) Latvijas Centrālās padomes vēstures nezināmās lappuses. Rīga : Latvijas vēstures institūta apgāds.

4 Neiburgs, U. (2011) Zviedru un amerikāņu izlūkdienestu loma Latvijas Centrālās padomes organizētajās bēgḷu laivu akcijās pāri Baltijas jūrai uz 
publikācijās. Plašas video intervijas ar V. Lasmani glabājas Latvijas Okupācijas muzeja Audiovizuālo materiālu krātuvē un audio ieraksti - Nacionālās mutvārdu vēstures krājumā Latvijas Universitātes Filozofijas un socioloğijas institūtā.

Valentīnes 100. dzimšanas diena kuplā draugu pulkā tika svinēta Latvijas Nacionālajā bibliotēkā 2016. gada 16. maijā, kad skaipā celıja apsveikumi no Rīgas uz Stokholmu. Tas bija tilts pāri jūrai un liecināja, ka, neskatoties uz ilgo prombūtni, Valentīnei ir noturīgas saites Latvijā. Pāri jūrai veda ceḷš arī vienā no Valentīnes dzīves kulminācijas brīžiem, kas aprakstīts viņas pašas sakopotajā 130 liecinieku atminu grāmatā Pāri jūrai 1944./45. g. (Memento, Stokholmā 1990. gadā).

Valentīnes gadsimta stāsts lobīts pakāpeniski - pēc daudzām sarunām, intervijām un vienkārši tikšanās reizēm, skaidrojot un precizējot to, ko vairs zināja tikai vina.

Stāstìt par savu dz̄ivi mutvārdu vēstures pētniecēm V. Lasmane sāka 1996. gadā Stokholmā. Kad abas ar kolēǵi Baibu Belu devāmies intervēt latviešus Zviedrijāa, Valentīne mums atvēelēja vietu pārnakšnošanai savā dzīvoklī. Kā vēlāk noskaidrojās, vinas viesmīlību baudījuši daudzi draugi, paziņas un paziņu paziñas. Jo viña - ja vien spēja, bija gatava palīdzēt visādos veidos. Valentīne labi saprata mūsu uzdevumu un iepazīstināja ar citiem latviešiem, kas vēlāk iekḷuva grāmatā Mès nebraucām uz Zviedriju, lai kḷūtu par zviedriem ${ }^{5}$. Gluži dabīgi raisījās sarunas pirms un pēc brokastīm vai pie vakarinu galda. Valentīnes stāstu uzklausījām kā daḷu no latviešu vēstures Zviedrijā, daļu no tās sabiedrības, kurai viņa pati piederēja jau 52 gadus un mums tikpat ilgi bijusi nepieejama. Bija vēl kāds apstāklis, kas sekmēja sadarbību. Valentīne gribēja izstāstīt rakstnieka meitai (zinātniecei B. Belai) par incidentu ar Alberta Bela romānu Bezmiegs 1970. gadā. Padomju Latvijas drošības dienestiem bija nācis ausīs, ka no Zviedrijas iebraukušais Lasmaṇu pāris mēǵinās vēl nepublicēto manuskriptu izvest uz ārzemēm.

Zviedriju: 1944-1945. gads. Latvijas Vēsturnieku komisijas raksti, 27. Rịga : Zinātne, 171-186.

5 Bela, B. (2010) Mēs nebraucām uz Zviedriju, lai kḷūtu par zviedriem. Rīga : Zinātne, 2010.
1996. gadā audio kasetēs tika ieskaṇots vairāku stundu garš atminu stāsts, kas gan atstāja vēl daudz nenoskaidrotu jautājumu. Vēlāk Valentīne posās braucieniem uz Latviju, un sarunas turpinājās 1997. gadā Rīgā, kad viṇa pati atnāca uz interviju Filozofijas un sociologijas institūtā, kas tolaik atradās Latvijas Zinātņu akadēmijas augstajā namā. Gatavojot grāmatu par Zviedrijas latviešu dzīvesstāstiem, intervijas turpinājās gan Stokholmā, gan Rīgā. Mainījās intervētāji, V. Lasmanes atmiņās aizvien parādījās jaunas detalias, ko, kā vēlāk noskaidrojās, palīdzēja atsvaidzināt viņas rūpīgi glabātie pieraksti, vēstules, dokumenti.

G. Grūtups sastapa Valentīni jau kā simtgadnieci, kad arī dzima ideja par grāmatu. Iestrādes bija, bet cik ilgs laiks dots atminuu kārtošanai un saskaṇošanai, to nezināja neviens. Tomēr atlika vēl divi autores dzīves gadi, kuros atklājās daudz kas no jauna, par ko Valentīne pati sāka runāt tikai mūža beigās. Tad viņa izcēla no plauktiem kārtīgi sarindotās mapes - savas dzīves hroniku. Tajās bija gan fotogrāfijas, pieraksti, vēstuḷu fragmenti, apsveikumi, izgriezumi no avīzēm, sarīkojumu biḷetes un programmas, nekrologi - konkrētā mirkḷa dokumentācija, kas piesaista atminu. Bez tam atradās arī vairākas dienasgrāmatas, ko rakstījusi viṇa pati, un otra, ko mantojumā atstājusi viņas mūža draudzene Olita Taube jeb dzejniece Anna Dagda. Grāmatā sastopas dažādos laikos un dažādās noskaṇās mūža pēdējos 20 gados stāstītie atmiņu fragmenti ar dz̄̄ves sākuma izjūtām. Pati atzīst, ka ar grūtībām spēj pazìt sevi dienasgrāmatās, kas rakstītas pamatskolas un gimnāzijas laikā. Neskatoties uz izejmateriāla dažādību, ar autores līdzdalību tapis vienlaidu teksts, kurā vēsturiskās liecības ne ortogrāfijas, ne kompozicionālā kārtojuma dēḷ nav sagrozītas. Atmiṇu publikācijās tas ir sevišķi svarīgs ētisks aspekts, jo garantē sākotnējā teksta korektu izmantojumu.

Valentīne līdz mūža beigām izlasīja visas svarīgākās grāmatas par Latvijas vēsturisko atmiṇu un kultūru. Vēl 2017. gadā viṇa uzrakstīja recenziju Latvijas Avīzē U. Neiburga grāmatai ${ }^{6}$, kurā izmantotas arī viņas atmiņas.

\footnotetext{
${ }^{6}$ Neiburgs, U. (2017) Draudu un cerību lokā: Latvijas pretošanās kustība un Rietumu sabiedrotie (1941-1945). Rīga : Mansards.
} 
Tūlīt pēc izlasīšanas viņa dalìjās ar Gundegu Grīnumu atzin̄ās par monogrāfiju Vinpus Alpiem $^{7}$. Valentīne pamanīja arī kḷūdas, kas rodas, ja publikācijā autors atmiņas neprecīzi interpretē, kā noticis ar Vinces Hanta literarizēto vēsturi ${ }^{8}$, kurā ir sajaukta Valentīnes un Leonīda Siliṇa loma bēgḷu laivu rīkošanā. Savu atmiṇu teksta tapšanai viņa sekoja vērīgi un pievērsa uzmanību, cik viegli, nodalot kādu fragmentu vai līdz galam neizprotot apstākḷus, par kuriem tiek stāstīts, var rasties neprecizitātes un pārpratumi. Autores līdzdalība grāmatas veidošanā ir svarīgs arguments arī tad, ja teksts tiek citēts turpmākos pētījumos un publikācijās.

Atmiņu stāsts ved pāri divu zemju un kultūru robežām, un daudz no tā, kas noticis, veidojies vienā pusēe, joprojām nav skaidrs otrā. Daudzas Zviedrijā pašsaprotamas reālijas nav pazīstamas Latvijā. Arī paradumi Valentīnes ǵimenē reizēm paliek ārpus kā latviskai, tā zviedriskai izpratnei. Viņa ir starpkultūru cilvēks plašākā nozīmē un arī domāšanas veidā.

Šì atšķirības izjūta sakņojas jau bērnībā. Valentīne nāk no jauktas ǵimenes, kur valdīja citāda attieksme, paradumi, nekā pieņemts sabiedrības vairākumā. Aizvien sekojot augstākiem ideāliem, pati sevī saskata trūkumus, kas neḷauj kḷūt augstprātīgai. Viņa apbrīno un ciena tos, no kuriem var gaidīt svarīgus lēmumus, izšķirošu rīcību - līdz brīdim, kad nākas vilties. Atmiṇās aizvien klātesoša ir draudzība un ar to saistītā morālā dimensija, kas visspilgtāk atspogul丷ojas dienasgrāmatas ierakstos un vēstulēs. Vienatne ar papīra lapu padziḷina pašvērtējošo attieksmi un spriedumus, kam ir svarīga loma izvēlēto ikdienas notikumu aprakstos. Dzīvesstāsts ar savu pieeju apliecina garīgo vērtību un cilvēku savstarpējo attieksmju ētikas nozīmi konfliktos un strīdīgās situācijās.

Grāmatas nosaukums tika noskatīts Valentīnes dienasgrāmatas pēdējā jaunā gada ierakstā: "2017. un 2018. gada mijā Valentīne savā pēdējā dzīvesvietā Tēbijā raksta, ka ir mierīga nakts, arī telefons klusē, jo visiem tuviniekiem

7 Grīnuma, G. (2017) Viṇpus Alpiem. Rainis un Aspazija Kastan,olā. Jaunatklāti tuvplāni. Rīga : Mansards.

8 Hunt, Vince (2017) Blood in the Forest: The End of the Second World War in the Courland Pocket. Solihull, UK : Helion \& Company. ir piekodināts, ka viṇai kā loti vecam cilvēkam nevajag tieši gadu mijā laimes vēlēt. Lai labāk Jaungada nakts rit mierīgi. Tomēr šajā gadu mijas naktī Valentīne nevar aizmigt. Tad viņa pieraksta: "Nakts jau nav tikai gulěšanai." Naktī no Kurzemes krasta devās viņas laivas uz brīvību, un, patiesi, nakts jau ir arī mīlestībai un nākotnes domām." (2020, 427)

Grāmatā izsijāts bagāts atmiņu materiāls un pavērts ceḷš caur dzīvi, kuru tā īsti novērtēt iespējams, tikai labi pārzinot Latvijas vēsturi. Un tomēr atmiñas dod vēl ko vairāk - tajās var dzīvot līdzi un just, saprast vēsturi cilvēka dzīves mērogā. Energisiski un reizēm ar humoru viņa ne tikai atklāj savu dzīves gājumu, bet arī sniedz sīkus atsevišķu notikumu aprakstus un personisko vērtējumu. Viñai piemīt spēja paskatīties uz sevi no malas, salīdzināt un noškirt no sabiedrībā populāriem cilvēkiem, ar kuriem vēlāk iepazīstas tuvāk: "Es nebiju nekas starp tiem, kas bija kaut kas." Un turpat arī piebilst: "Bet es arī negribēju būt kaut kas." (2020, 437)

Daudzviet individuālā Valentīnes dzīve cieši iekḷāvusies Latvijas valsts dzīves notikumos. Pie kam ar kaismīgu vēlmi - piedalīties, veidot, vērst visu uz labu. Vācu okupācijas laikā 1941. gadā Valentīne piedzīvo to, kas vēsturē ierakstīts kā holokausta traǵēdija, kad Malnavas lauksaimniecības vidusskolā nacisti iesaista skolniekus ebreju slepkavošanā. 1944. gadā Valentīne iesaistās Latvijas Centrālās padomes (LCP) pretestības kustībā, tiekas ar vadītāju Konstantīnu Čaksti. Pēc tam dodas uz Ventspili, lai kopā ar Latvijas Centrālās padomes Ventspils sakaru grupu Valdemāra G̣intera vadībā kārtotu bēg̣̣u laivu kustību pāri jūrai. LCP ir latviešu inteliğences, bijušās Saeimas deputātu, reliǵisko organizāciju pārstāvju izveidota kustība ar mērķi pēc kara atjaunot neatkarīgas valsts pārvaldi. Viena no tās redzamākajām aktivitātēm - bēg̣̣u laivu pārcelšana pāri jūrai uz neitrālo Zviedriju.

Valentīnes gaitas turpinās arī pēc LCP vadības aresta, darbojoties vēl padomju neokupētajā Kurzemē. Šeit Valentīne nesekmīgi mēǵina pierunāt kureliešu grupas vadību doties pāri jūrai uz Zviedriju. Dienu vēlāk vācieši atbruṇo kureliešus, bet vadība tiek arestēta un iznīcināta.

Valentīne raksta: "Pēc LCP nostādnēm mūsu mērḳis bija aizvest no Latvijas nevis pēc 
iespējas vairāk cilvēku, bet gan tos, kas Latvijā ir apdraudēti, īpaši politiķus, sabiedriskos darbiniekus, kas, emigrācijā darbojoties, spētu starptautiski pieprasīt Latvijas valsts atjaunošanu." 1944. gada rudenī Valentīne Kurzemes mežos sameklē izbēgušo ebreju Michelsonu. Un 26. novembrī vini kopā izkāpj no pārcēlāju Ërika Tomsona un Ž̉aṇa Fronzova vadītās laivas Zvejnieks Gotlandes krastā.

Turpinājumā var sekot Valentīnes centieniem dzīvot trimdā un darboties, lai ne trimdas, ne starptautiskā sabiedrība neaizmirst Latvijas okupācijas nelikumību, lai aizstāvētu cilvēktiesības un iestātos par padomju politieslodzīto atbrīvošanu. Viņas vīra māsas Lidijas Lasmanes-Doroninas atkārtotie aresti raksturo padomju represiju viļ̧̧us okupētajā Latvijā: 1970. gadā, kad Lidiju arestē otro reizi, Valentīne ar vīru viesojas Latvijā un piedzīvo pratināšanu Valsts drošǐbas komitejā. Pēc Lidijas aresta 1983. gadā Valentīne rīko protesta demonstrācijas Rietumos, iesaistās latviešu teologa Pauḷa Kḷaviņa iniciētajā Gaismas akcijā Padomju Savienības politieslodzīto atbalstam: "Izkāpjot no laivas Gotlandē, man bija divdesmit astoņi gadi. No tiem Latvijā biju dzīvojusi divdesmit divus, jo mani pirmie seši gadi taču pagāja Ukrainā. Tagad, vecumdienās Zviedrijā, tuvinieki man ir neizpratnē jautājuši: "Nu, kāpēc tu par to Latviju un Latviju? Cik tad tu tur esi dzīvojusi?!" Tiešām maz. Taču man ir tāda sajūta, ka kultūras zin̄ā ir svarīgi, ko viena tauta dod cilvēcei. Un latviešiem vēl ir jādod iespēja savu identitāti izdzīvot. Vēl latviešiem ir un top tas ļoti smalkais, kas mūs atšķir no citām tautām. Nacionāla valsts palīdz tautai savu kultūru saglabāt." $(2020,205)$

Vēl daži vārdi par grāmatas tapšanā iesaistīto komandu, ko izvēlējās pati Valentīne. Idejas autors Gaitis Grūtups iepriekš bija strādājis ne ar vienu vien atmiṇu materiālu un sagatavojis grāmatu ar Hugo Legzdiña, Latvijas zemūdenes Ronis pēdējā komandiera, atmin̄ām, ar jaunās meitenes Maigas kara laikā aprauto dienasgrāmatu, ar Žaņa Skudras literāro mantojumu. Pēc sastapšanās ar Valentīni G. Grūtups saprata, ka vinas dzīve nevar palikt bez grāmatas. Tā sākās Valentīnes pēdējo mūža gadu trejpusējā sadarbība ar žurnālistu Gaiti un mutvārdu vēstures pētnieku darbistabu.
Pie kam pēdējā bija manuskriptu pārsūtīšanas centrs: redaktora sagatavotie atminu fragmenti tika nodoti "kurjerēm" - Petrai Ininbergai vai Mārai Strautmanei, kuras tos nogādāja Valentīnei Stokholmā un atpakal jau ar piezīmēm, labojumiem, papildinājumiem. Tad Valentīne visus pārsteidza ar vērienīgu sūtījumu: 10 mapēm ar izgriezumiem no drukātiem tekstiem, vēstulēm, notikumu pierakstiem - pašas kārtotu atmiņu piesaisti, kas pavadījusi viņas dzīves gadus.

Kad teksts bija attiecīgi labots, tika iesaistīta Valentīnes pašas izvēlēta konsultante ar pieredzi Zviedrijas dzīvē - literatūrzinātniece un valodniece Aija Priedīte. Viņa palīdzēja orientēties Valentīnes atminu plašajā kultūras ǵeogrāfijā. Savukārt Kaspars Zellis sniedza skaidrojumus Latvijas vēsturē. Grāmatas tapšanu nostiprināja vienošanās, kuru Valentīne parakstīja, uzticēdama savu atmiṇu stāstus un rakstus Latvijas Mutvārdu vēstures pētnieku asociācijai Dzīvesstāsts. Kārtojot un saglabājot savu atmiņu liecības, viņa arī pati veicināja dzīvesstāstu pētnieku misiju un, gluži tāpat kā savā laikā Melānija Vanaga, labprāt atsaucās aicinājumam kḷūt par asociācijas goda biedri.

Pēdējā laikā saziṇa ar Valentīni notika telefona sarunās, kas, pateicoties LMT tîkla Eiropas tarifiem, bija kḷuvušas pieejamas. Un sarunās aizritēja stundas, kā Gaitim Grūtupam, tā Aijai Priedītei un man. Valentīne azartiski iesaistījās sacensībā ar laiku. Ja saka, ka cilvēks mirstot pēdējā mirklī pārredz savu dzīvi, tad Valentīnei šis mirklis ietvēra pēdējos mūža gadus, kas aiztraucās intensīvā garīgā un atminuu piesātinātā darbā. Līdz 2018. gada novembra beigām, kad viņa pamazām sāka no mums atvadīties, līdz pēdējai sarunai 30. novembrī. No dzīves Valentīne šḳīās 3. decembrī (2018), kad bija pasaulē nodzīvojusi 102 ar pusi gadus.

Grāmata ir tapusi ar Valsts kultūrkapitāla fonda un "Latviešu Fonda" (ASV), ar PBLA KF un Zviedrijas latviešu organizāciju atbalstu, ar daudzu cilvēku atsaucību un palīdzību, kas jo sevišķi bija nepieciešama, veidojot atminu stāstā pieminēto personu rādītāju vai, kā mēs paši to nosaucām, - mini enciklopēdiju, kuras apjoms vien raksturo V. Lasmanes atmiņu stāsta vērienu. 